Research Paper

\title{
Downregulation of Nitric Oxide Collaborated with Radiotherapy to Promote Anti-Tumor Immune Response via Inducing CD8+ T Cell Infiltration
}

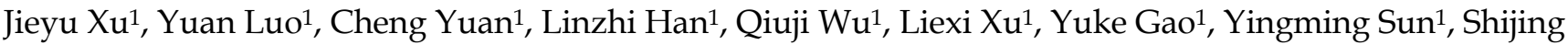 \\ $\mathrm{Ma}^{1}$, Guiliang Tang${ }^{1}$, Shuying Li1 ${ }^{1}$, Wenjie Sun ${ }^{1}$, Yan Gong ${ }^{2}$, Conghua $\mathrm{Xie}^{1,3,4}$ \\ 1. Department of Radiation and Medical Oncology, Zhongnan Hospital of Wuhan University, Wuhan, China \\ 2. Department of Biological Repositories, Zhongnan Hospital of Wuhan University, Wuhan, China \\ 3. Hubei Key Laboratory of Tumour Biological Behaviors, Zhongnan Hospital of Wuhan University, Wuhan, China \\ 4. Hubei Cancer Clinical Study Center, Zhongnan Hospital of Wuhan University, Wuhan, China \\ $\bowtie$ Corresponding authors: Dr. Conghua Xie, Email: chxie_65@whu.edu.cn, Tel: +86-27-67812607, Fax: +86-27-67812892; and Dr. Yan Gong, Email: \\ yan.gong@whu.edu.cn, Tel: +86-27-67811461, Fax: +86-27-67811471
}

(C) The author(s). This is an open access article distributed under the terms of the Creative Commons Attribution License (https://creativecommons.org/licenses/by/4.0/). See http://ivyspring.com/terms for full terms and conditions.

Received: 2019.10.30; Accepted: 2020.02.15; Published: 2020.03.05

\begin{abstract}
The production of nitric oxide (NO) is a key feature of immunosuppressive myeloid cells, which impair T cell activation and proliferation via reversibly blocking interleukin-2 receptor signaling. NO is mainly produced from L-arginine by inducible NO synthase (iNOS). Moreover, L-arginine is an essential element for $\mathrm{T}$ cell proliferation and behaviors. Impaired $\mathrm{T}$ cell function further inhibits anti-tumor immunity and promotes tumor progression. Previous studies indicated that radiotherapy activated anti-tumor immune responses in multiple tumors. However, myeloid-derived cells in the tumor microenvironment may neutralize these responses. We hypothesized that iNOS, as an important regulator of the immunosuppressive effects in myeloid-derived cells, mediated radiation resistance of cancer cells. In this study, we used 1400W dihydrochloride, a potent small-molecule inhibitor of iNOS, to explore the regulatory roles of NO in anti-tumor immunity. Radiotherapy and iNOS inhibition by $1400 \mathrm{~W}$ collaboratively suppressed tumor growth and increased survival time, as well as increased tumor-infiltrating $\mathrm{CD} 8^{+} \mathrm{T}$ cells and specific inflammatory cytokine levels, in both lung and breast cancer cells in vivo. Our results also suggested that myeloid cell-mediated inhibition of T cell proliferation was effectively counteracted by radiation and 1400W-mediated NO blockade in vitro. Thus, these results demonstrated that iNOS was an important regulator of radiotherapy-induced antitumor immune responses. The combination of radiotherapy with iNOS blockade might be an effective therapy to improve the response of tumors to clinical radiation.
\end{abstract}

Key words: iNOS, myeloid cells, radiotherapy, immunotherapy, tumor microenvironment

\section{Introduction}

Immunotherapy plays increasingly important roles during tumor treatment, especially in assisting radiotherapy (RT) to improve clinical outcomes. However, RT has inhibitory effects on immune activation through various mechanisms. Radiation can recruit myeloid-derived suppressive cells that inhibit the activation and function of $\mathrm{T}$ cells [1-5]. Tumor-infiltrating myeloid-derived cells are mainly composed of dendritic cells, myeloid-derived suppressor cells (MDSCs), polymorphonuclear neutrophils, and tumor-associated macrophages (TAMs) [6-8].

The general characteristic of these cells is the production of nitric oxide (NO) [4, 9-11]. The synthesis of NO is catalyzed by NO synthase (NOS), using L-arginine as the substrate [12]. There are 3 known isoforms of NOS: neuronal NOS (nNOS), inducible NOS (iNOS), and endothelial NOS (eNOS) 
[13], of which iNOS is the majority one [14, 15]. NO can directly suppress the activation and proliferation of $\mathrm{T}$ cells by reversibly intercepting signals through the interleukin (IL)-2 receptor and inducing $\mathrm{T}$ cell apoptosis [2-4]. iNOS can produce $\mathrm{NO}$ and thus deplete L-arginine, which is an essential nutrient for the activation and functional expression of $\mathrm{T}$ cells [16-18].

Experimental data indicated that immune responses activated by $\mathrm{RT}$ could be impeded by production of NO. L-n6-(1-iminoethyl)-lysine (L-NIL), as a potent iNOS inhibitor, enhanced RT susceptibility of treatment-refractory head and neck cancer $[19,20]$. Moreover, NO reduction with a highly-selective NOS inhibitor, NG-monomethyl-L-arginine monoacetate (LNMMA), enhanced the radiosensitization of nonsmall cell lung cancer (NSCLC) cells [21]. However, the underlying mechanism was still to be investigated. Therefore, we hypothesized that inhibition of iNOS could effectively alleviate RT-inhibited of immune system activation and promoted $\mathrm{T}$ cell function via suppressing NO synthesis in immunosuppressive myeloid cells, thereby further enhanced the efficacy and clinical outcomes of RT.

In the present study, we assessed the efficacy of the small-molecule inhibitor of iNOS, 1400W dihydrochloride, using xenograft mouse models in vivo. The results showed that $1400 \mathrm{~W}$ combined with RT treatment significantly suppressed tumor growth and extended survival time. Immune cells in the tumor microenvironment and spleen tissues were further analyzed to explore the mechanism of the inhibitory effects of iNOS inhibitor. An increased number of tumor-infiltrating $\mathrm{CD}^{+} \mathrm{T}$ lymphocytes was detected in the combined treatment group. Similarly, the numbers of $\mathrm{CD}^{+}$and $\mathrm{CD}^{+} \mathrm{T}$ lymphocytes in the spleen increased significantly. We further validated our hypothesis with $\mathrm{T}$ cell proliferation assay in vitro. Our results indicated that iNOS inhibition combined with RT collaboratively suppressed tumor growth, providing a new strategy for cancer immunotherapy.

\section{Materials and Methods}

\section{Mice}

Female C57BL/6 (6-8 weeks old) and Balb/c mice (5-7 weeks old) were supplied by Vital River Laboratory Animal Technology (Beijing, China) and housed in a specific-pathogen-free environment. All animal experiments were approved by the Institutional Animal Care and Use Committee of Wuhan University. The animals were sacrificed when reached the Mice Welfare Endpoint.

\section{Cells and reagents}

Lewis lung carcinoma (LLC), 4T1, THP-1 and Jurkat cells were purchased from the Cell Resource Center of the Shanghai Institutes for Biological Sciences of the Chinese Academy of Sciences (Shanghai, China). LLC and 4T1 cells were cultured in DMEM (HyClone, Logan, USA) supplemented with $10 \%$ fetal bovine serum and $1 \%$ glutamine-penicillinstreptomycin at $37{ }^{\circ} \mathrm{C}$ in a $10 \% \mathrm{CO}_{2}$ atmosphere. THP-1 and Jurkat cells were cultured in RPMI-1640 medium (HyClone) supplemented with 15\% inactivated fetal bovine serum and $1 \%$ glutaminepenicillin-streptomycin at $37^{\circ} \mathrm{C}$ in a $10 \% \mathrm{CO}_{2}$ atmosphere. LLC-luc and 4T1-luc cells were generated by luciferase lentivirus (LV-NC, OBiO Technology, Shanghai, China) infection and puromycin (Cayman Chemical, Ann Arbor, USA) selection (3 mg/mL for LLC and $2 \mathrm{mg} / \mathrm{mL}$ for 4T1). 1400W dihydrochloride, a potent small-molecule inhibitor of iNOS, was purchased from MedChemExpress (Monmouth Junction, USA).

\section{Tumor inoculation and treatment}

C57BL/6 and Balb/c mice were injected subcutaneously with $1 \times 10^{6}$ LLC-luc or 4T1-luc cells in the left lower flank respectively [22]. When the tumor size reached approximately $120 \mathrm{~mm}^{3}$, mice were randomly grouped: control, radiation, iNOS inhibition, radiation and iNOS inhibition. X-ray fluoroscopy was used to verify the completed foci of the irradiated field and tumors were then irradiated with a dose of 6 Gy $\times 5$, using a small animal irradiation research platform (PXI X-RAD 225Cx, Precision X-Ray, North Branford, USA; Fig. 1A\&B). Tumor volume was measured using a Vernier caliper every other day and calculated according to the formula: length $\times$ width $\times$ width/2. 1400W or vehicle control (phosphatebuffered saline, PBS) were administered intraperitoneally ( $200 \mu \mathrm{g} /$ mouse) every day from day 8 for LLC and day 5 for $4 \mathrm{~T} 1$ [23].

For in vivo bioluminescence imaging, mice were anesthetized with pentobarbital (Sigma Chemical, St Louis, USA). D-luciferin (PerkinElmer, Waltham, USA) was intraperitoneally injected into the belly, and images were captured using an IVIS Lumina XRMS Series III imaging system (PerkinElmer). $\mathrm{CD}^{+}$and $\mathrm{CD}^{+} \mathrm{T}$ cells were depleted by intraperitoneally injecting $250 \mathrm{mg}$ of monoclonal a-CD4 (GK1.5 clone, BioXCell, West Lebanon, USA) and a-CD8 (2.43 clone, BioXCell) antibodies, and depletion was confirmed by mononuclear cell staining in peripheral blood. Animals were sacrificed according to humane endpoint guidelines: tumors necrotized or reached the size of approximately $2,000 \mathrm{~mm}^{3}$. 
For survival analysis, each group was stated with 9 to 10 mice. In addition to death, mice were sacrificed when the following points were reached: 1 , tumors necrotized or reached the size of approximately $2,000 \mathrm{~mm}^{3} ; 2$, the tumor influenced breathing, eating, walking and any other physiologic functions; 3, rupture appears on the surface of the tumor. Log-rank tests were used to assess differences in survival.

\section{Flow cytometry}

Single-cell suspensions were generated by tumor excision and collagenase digestion. The cells were then stained with fluorescence-labeled antibodies against CD4 (BD Biosciences, Franklin Lakes, USA), CD8 (BD Biosciences), and CD45 (BD Biosciences). The samples were examined by FACS Aria TM III Cell Sorter (BD Biosciences) and data were analyzed with FlowJo software.

\section{Serum cytokine analysis}

Serum samples were collected by centrifuging peripheral blood at 5,000 rpm for $5 \mathrm{~min}$ and then at $3000 \mathrm{rpm}$ for $5 \mathrm{~min}$. The levels $(\mathrm{pg} / \mathrm{mL}$ ) of interleukin (IL)-2, IL-4, IL-5, and interferon (IFN)- $\gamma$ in the serum samples were assessed using Cytometric Bead Array (CBA) Mouse Th1/Th2 Cytokine Kit (BD Biosciences) according to the manufacturer's instructions. The samples were then analyzed using a FACS Aria TM III Cell sorter and data were analyzed using $\mathrm{BD}$ Biosciences CBA software.

\section{$\mathbf{T}$ cell proliferation assay}

THP-1 cells were seeded into 6-well plates and induced with phorbol 12-myristate 13-acetate. After incubation for $12 \mathrm{~h}$ and observation of adherent growth, the THP-1 cells were randomized into 4 groups treated as follows: blank control, 4 Gy radiation, $1400 \mathrm{~W}$ treatment $(60 \mu \mathrm{M}), 4$ Gy radiation combined with $1400 \mathrm{~W}$ treatment $(60 \mu \mathrm{M})$ [24]. After incubation for $12 \mathrm{~h}$ and $24 \mathrm{~h}$, the supernatant was collected and applied to Jurkat cells cultured in 6-well plates. The numbers of viable cells were calculated using a blood cell counting plate $24 \mathrm{~h}$ later.

\section{Statistical analysis}

All experiments were performed in triplicates. Results are expressed as mean \pm SEM. The unpaired Student $t$ test was used to analyze cytokine levels and cell numbers between groups. Treatment effects on tumor growth were assessed using One-way analysis of variance. Log-rank tests were used to assess differences in survival. $P$ values less than 0.05 were considered statistically significant.

\section{Results}

\section{iNOS inhibition and RT cooperatively suppressed tumor growth}

$1400 \mathrm{~W}$ was previously reported to efficiently inhibit iNOS and widely used as iNOS inhibitor [24-26]. To determine whether 1400W inhibited tumor growth and enhanced RT efficacy, its effects in both lung and breast cancer cells were examined in the xenograft mouse models. Changes in tumor volume were recorded and tumor growth curves were plotted to investigate the efficacy of $1400 \mathrm{~W}$ alone or in combination with RT in tumor-bearing mice (Fig. $1 C \& D)$. Treatment with $1400 \mathrm{~W}$ alone had no substantial effect on tumor growth, but significantly suppressed tumor growth in the combined treatment group compared with the single-fractionated RT group $(P<0.05)$. To further observe whether iNOS inhibition improved the therapeutic effect of RT, survival analysis was performed. Our results indicated that combination therapy effectively prolonged survival time (Fig. 1E). In vivo imaging results also demonstrated that $1400 \mathrm{~W}$ combined with RT collaboratively inhibited tumor progression than RT alone (Fig. 1F). All of the above experimental results indicated the synergistic effects of iNOS inhibition and RT on inhibiting tumor growth.

To investigate the efficacy of iNOS inhibition in other tumors, a 4T1 tumor model was subsequently established and when the tumors were palpable, mice were randomly assigned to four groups and treated as described above (Fig. 2A). Similar to the LLC model, no significant effect on tumor growth was observed in the group administered 1400W alone. However, iNOS inhibition significantly delayed 4T1 tumor progression when combined with RT (Fig. $2 \mathrm{~B}, P<0.05$ ). In vivo imaging of tumor-bearing Balb/c mice also indicated that the combination of $1400 \mathrm{~W}$ and RT inhibited tumor growth to a greater extent than individual RT treatment in the breast cancer model (Fig. 2C).

\section{iNOS inhibition potentiated the therapeutic effects of $R T$ in a $T$ cell-dependent manner}

Myeloid-derived suppressive cells inhibit $\mathrm{T}$ cell proliferation and function, suppressing immune system activation, and iNOS is involved in the regulation of this process. Based on the results above, the possible relationship between tumor growth delay and activation of the immune system was further investigated. Tumor-bearing C57BL/6 mice were sacrificed 5 days after irradiation treatment. Tumor tissues and spleens were excised for $\mathrm{T}$ lymphocyte analysis. After tumor digestion with collagenase, single-cell suspensions were stained with 
fluorescence-labeled CD45, CD8, and CD4 antibodies. The results indicated that the percentage of tumor-infiltrating $\mathrm{CD}_{4} 5^{+}$cells was collaboratively upregulated by iNOS inhibition and RT (Fig. 3A\&B, $P$ $<0.05$ ). iNOS inhibition combined with RT also markedly increased the percentage of $\mathrm{CD} 45^{+} \mathrm{CD} 8^{+} \mathrm{T}$ cells in lung cancer tissues (Fig. 3C; $P<0.05$ ). Examination of $\mathrm{CD}^{+}$and $\mathrm{CD}^{+} \mathrm{T}$ cells in the spleen also showed that the group receiving combined treatment had a notable increase in the percentage of $\mathrm{CD}^{+}$and $\mathrm{CD}^{+} \mathrm{T}$ cells compared with single treatment groups (Fig. 3D-F). MDSCs in the tumor microenvironment were also detected by flow cytometry, but no statistically significant differences were found between the groups (Fig. 4).

In addition to flow cytometry, immunohistochemistry also showed that iNOS inhibition combined with radiation significantly increased $\mathrm{CD}^{+}$and $\mathrm{CD} 8^{+}$ $\mathrm{T}$ cells in lung cancer tissues (Fig. 5A-C). A $\mathrm{CD}^{+} / \mathrm{CD}^{+} \mathrm{T}$ cell depletion experiment was used to further confirm these results (Fig. 5D). Depletion of $\mathrm{CD}^{+} \mathrm{T}$ cells effectively abrogated the antitumor effects of the combined therapy. However, a delay in tumor growth with combined treatment was still observed after $\mathrm{CD}^{+} \mathrm{T}$ cell depletion (Fig. 5E\&F). Successful depletion was verified in peripheral blood (Fig. 5G).
A

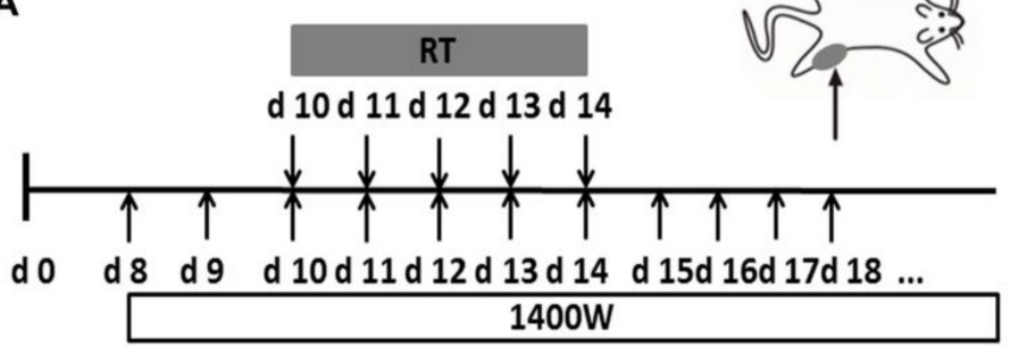

B

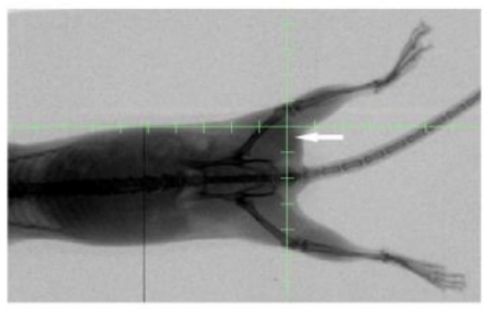

C
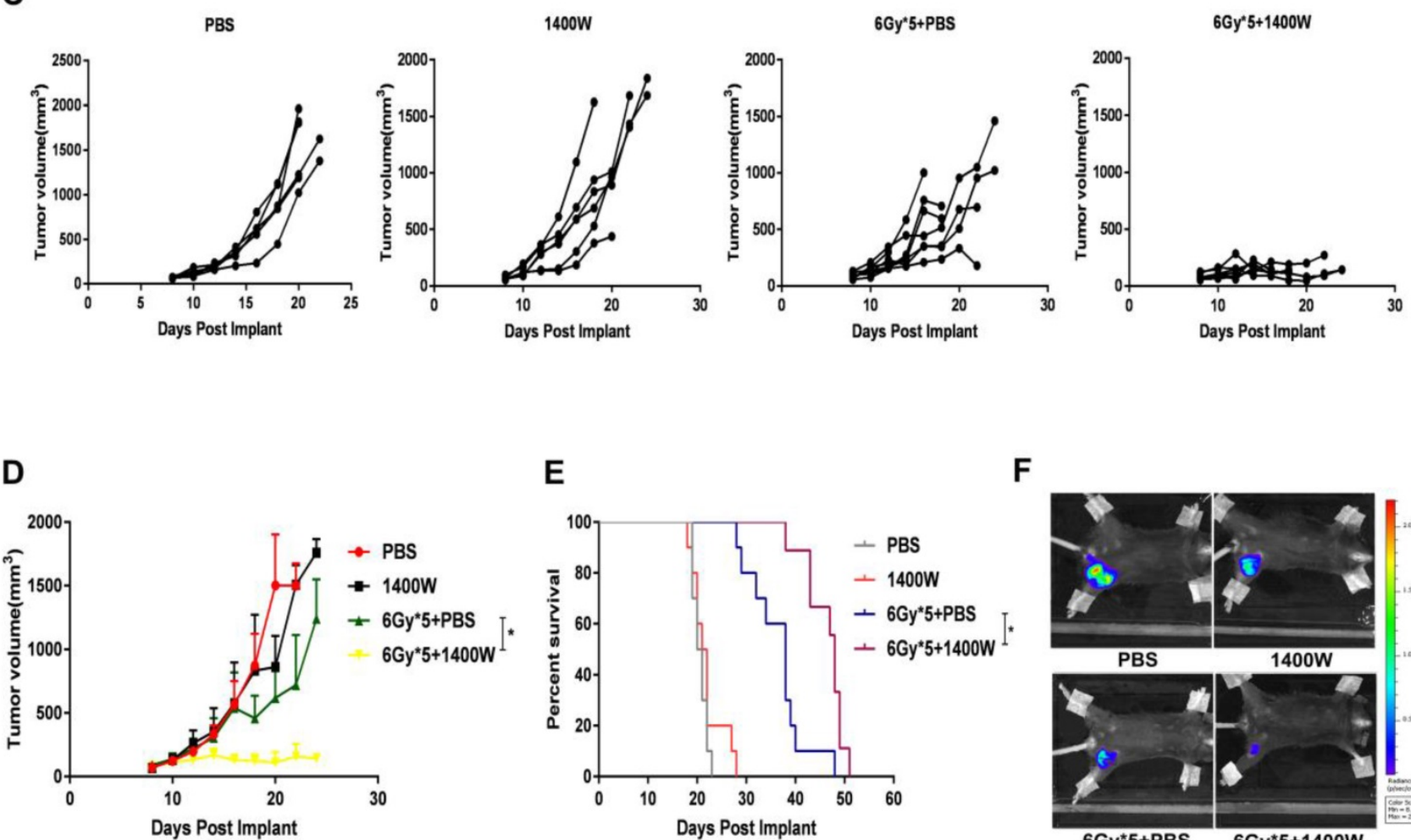

E

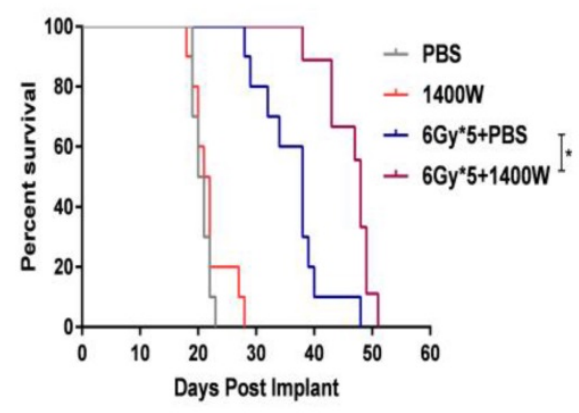

$\mathbf{F}$

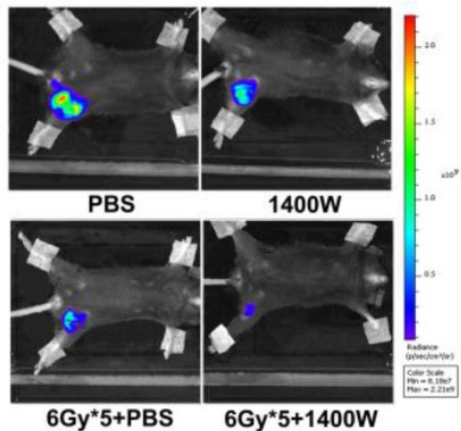

Figure 1. iNOS inhibition enhanced lung cancer cell radiosensitivity in vivo. (A): Treatment schema of lung cancer xenograft mouse study. (B): Representative $X$-ray image of positioning verification before irradiation. (C): Individual mouse tumor growth curves. (D): Mean tumor volume of each group. *, $P<0.05$. (E): Survival curves. PBS (n $=10), 1400 \mathrm{~W}(\mathrm{n}=10), 6 \mathrm{~Gy} \times 5+\mathrm{PBS}(\mathrm{n}=10), 6 \mathrm{~Gy} \times 5+1400 \mathrm{~W}(\mathrm{n}=9)$. *, $P<0.05$. (F): Representative in vivo images of each group. *, $P<0.05$. 


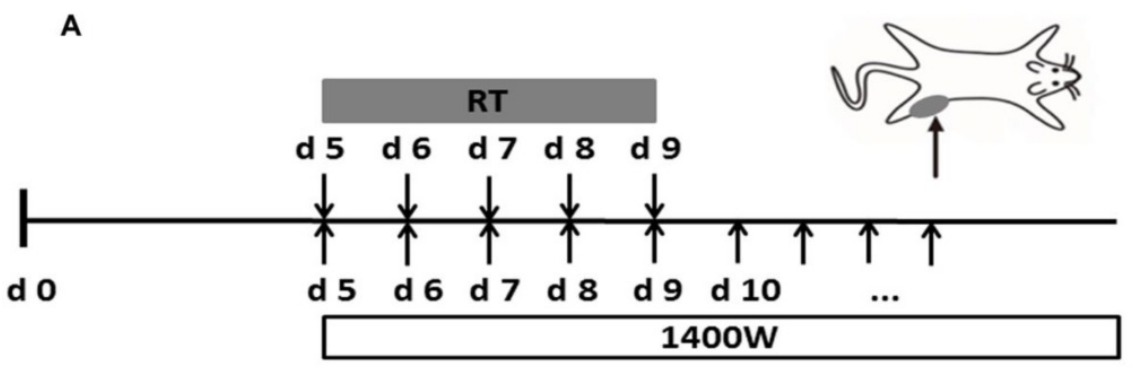

B

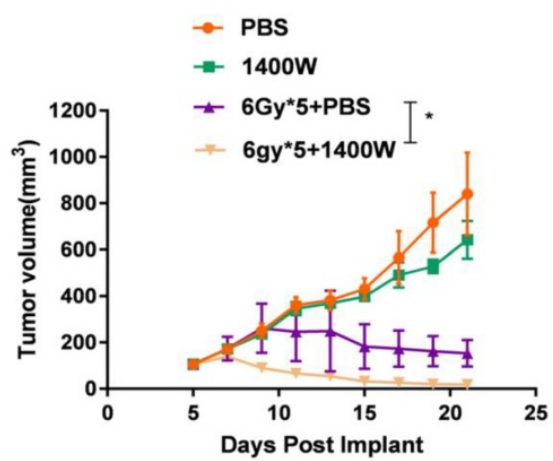

C

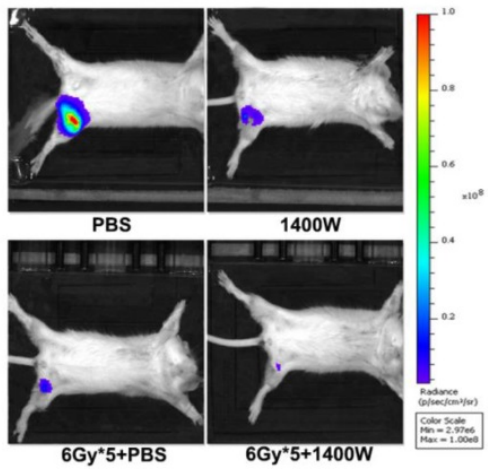

Figure 2. iNOS inhibition enhanced breast cancer cell radiosensitivity in vivo. (A): Treatment schema of breast cancer xenograft mouse study. (B): Tumor growth curves. *, $P<0.05$. (C): Representative in vivo images of each group. $\mathrm{n}=9-10 ; *, P<0.05$.

To investigate the serum levels of IL-2, IL-4, IL-5, and IFN- $\gamma$, a CBA Mouse Th1/Th2 Cytokine Kit was used. A statistically significant upregulation of IL-2 and IFN- $\gamma$ was seen in serum collected from the peripheral blood of tumor-bearing mice treated with 1400W and RT (Fig. 6). Hematoxylin and eosin staining of liver and kidney tissues indicated that 1400W had no obvious organ toxicity (Fig. 7).

These results suggested that iNOS inhibition markedly improved the therapeutic effects of RT by upregulating $\mathrm{T}$ cell proliferation, thus enhancing the activation of the immune system.

\section{iNOS inhibition neutralized the myeloid cell-induced inhibition of $\mathrm{T}$ cell proliferation in vitro}

To determine whether the myeloid cell-induced inhibition of $T$ cell proliferation could be counteracted by iNOS inhibition, a cell co-culture experiment was designed. After irradiated THP-1 cells were incubated for $12 \mathrm{~h}$ and $24 \mathrm{~h}$ (Fig. 8), the supernatant was collected and applied to Jurkat cells. Jurkat cells were incubated for $24 \mathrm{~h}$, after which the number of viable cells was calculated using a blood cell counting plate (Fig. 8A\&B). These data indicated a statistically significant increase in the number of $\mathrm{T}$ cells in the group treated with $1400 \mathrm{~W}$ alone, compared with the control group. iNOS inhibition combined with RT also resulted in increased $\mathrm{T}$ cell proliferation compared to RT alone. Thus, we concluded that $1400 \mathrm{~W}$ counteracted the myeloid cell-induced inhibition of $\mathrm{T}$ cell proliferation in vitro.

\section{Discussion}

Advances in immunotherapy drew increasing attention of cancer treatment recently. In particular, the combination of immunotherapy and traditional RT had substantial progress to improve clinical outcomes [27, 28]. RT was reported to activate immune system and prime $\mathrm{T}$ cells to tumor antigens $[29$, 30]. However, immunosuppressive myeloidderived cells, recruited by ionizing radiation, inhibited the activation and proliferation of $\mathrm{T}$ cells by producing NO, catalyzed by iNOS [2-4, 31, 32].

Therefore, we reasoned that increased iNOS levels would be immunosuppressive in the tumor environment for the following reasons. Firstly, NO production suppresses the $\mathrm{T}$ cell function through divergent mechanisms that involve reversibly blocking signaling through the IL-2 receptor, inhibiting the expression of MHC class II molecules, suppressing the function of JAK3 and STAT5 in T cells, and mediating the apoptosis of T cells [2-4, 33, 34]. Secondly, L-arginine is indispensable for the proliferation of cytotoxic lymphocytes, but it can be depleted by iNOS [16-18, 35-38]. Lastly, iNOS is over-expressed in many cancers, including melanoma and gastric, breast, colon, and head and neck carcinomas [39-43]. Additionally, clinical data shows that iNOS levels may be a predictor of poor survival [44]. 
A

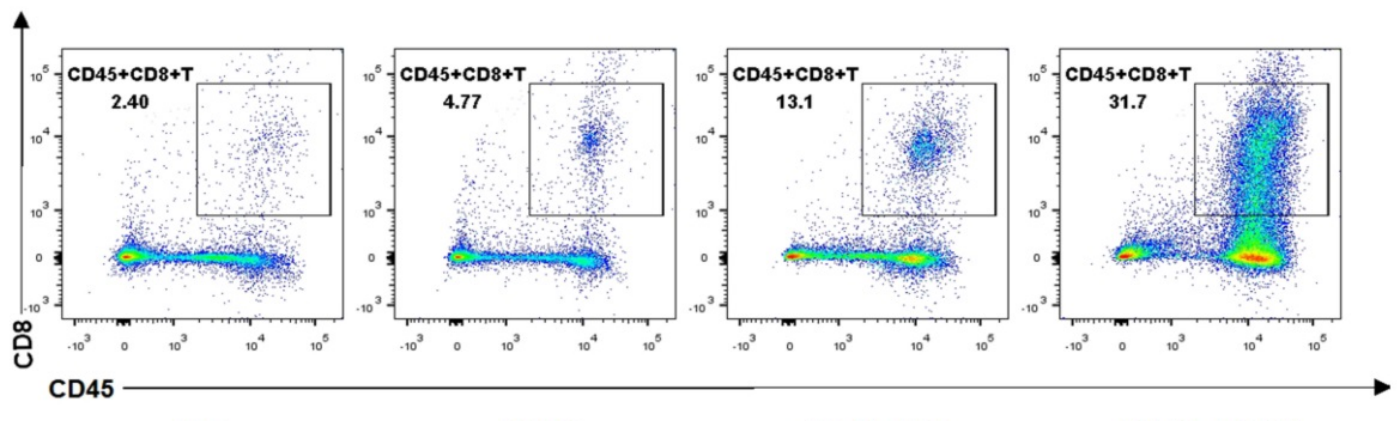

B

PBS

1400w

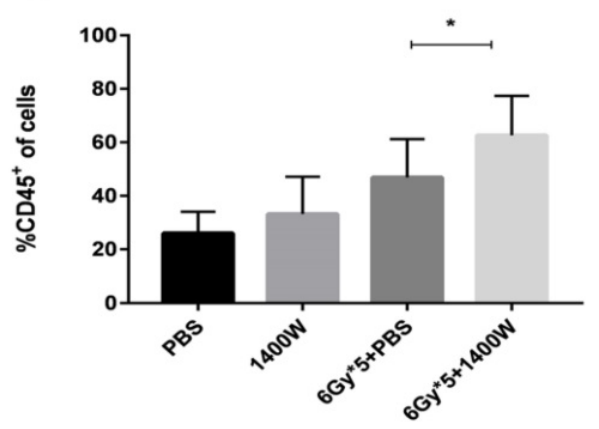

$C^{6 G y^{\star} 5+P B S}$

$6 G y^{*} 5+1400 W$
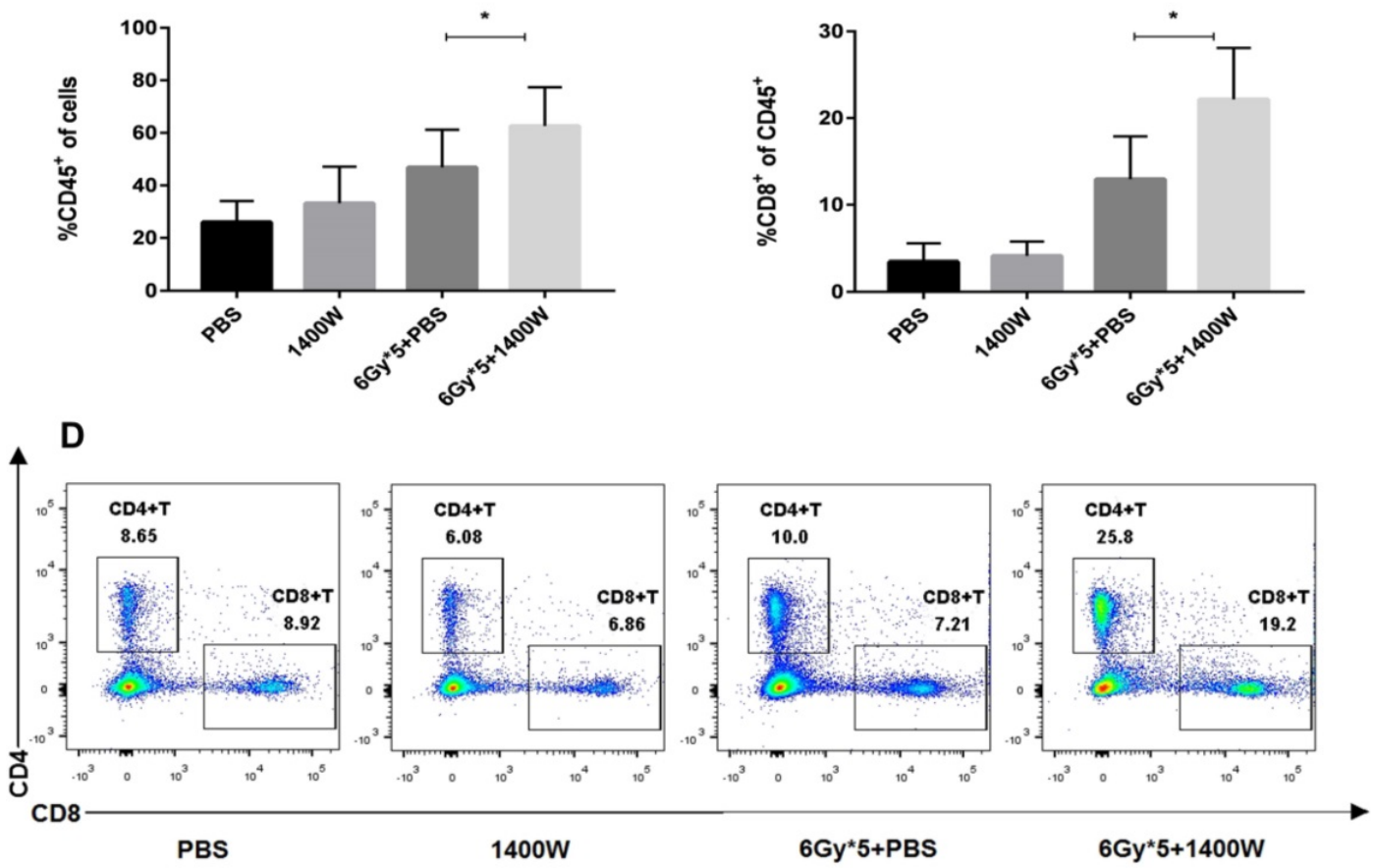

E

$\mathbf{F}$
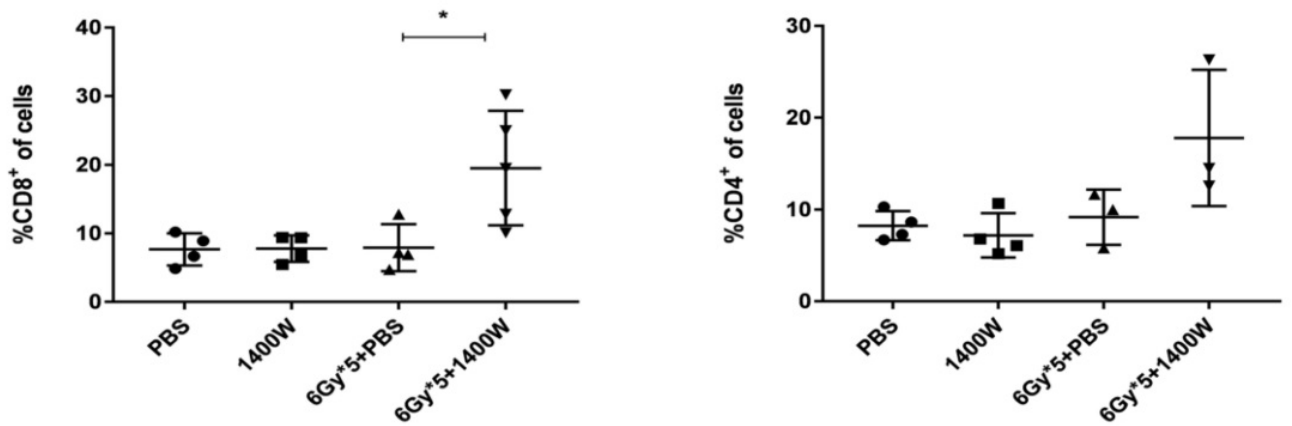

Figure 3. iNOS inhibition combined with RT to alter the levels of tumor- and spleen-infiltrating $\mathbf{T}$ lymphocytes. Tumor tissues were excised and serum samples were collected from peripheral blood 5 days after $\mathrm{RT}$. (A): Representative cytometry of tumor-infiltrating $C D 45^{+}$and $C D 8^{+}$lymphocytes in the lung cancer tissues. $n \geq 3 ; *, P<$ 0.05. (B): Quantitative analysis of tumor-infiltrating CD45+ $T$ cells in the lung cancer tissues. $n \geq 3 ; *, P<0.05$. (C): Quantitative analysis of tumor-infiltrating $C D 45+C D 8^{+} T$ cells in the lung cancer tissues. $n \geq 3 ; *, P<0.05$. (D): Representative cytometry of CD8 ${ }^{+}$and CD4+ $T$ cells in the spleen. $n \geq 3 ; *, P<0.05$. (E): Quantitative analysis of CD8+ $T$ cells in the spleen. $\mathrm{n} \geq 3 ;{ }^{*}, \mathrm{P}<0.05$. $(\mathrm{F})$ : Quantitative analysis of $\mathrm{CD} 4{ }^{+} \mathrm{T}$ cells in the spleen. $\mathrm{n} \geq 3 ; *, P<0.05$.

We previously reported that RT-induced $\mathrm{T}$ cell initiation can be inhibited by iNOS [12]. In this study, we showed that blocking iNOS in combination with RT effectively slowed tumor growth and prolonged survival in a mice model. It has been reported that RT alone can recruit $\mathrm{CD}^{+} \mathrm{T}$ cells to irradiated tumors [30, 45 , 46]. Our current data also showed that RT alone primed $\mathrm{CD} 8^{+} \mathrm{T}$ cells in established tumors. However, combined therapy resulted in a more pronounced increase in $\mathrm{CD}^{+} \mathrm{T}$ cell infiltration. 
The $\mathrm{CD}^{+} \mathrm{T}$ cell population is composed of several subgroups, such as Th1, Th2, and Tregs, of which Th2 $\mathrm{CD}^{+} \mathrm{T}$ cells and Tregs act as immunosuppressive cells. Thus, there is skepticism regarding the anti-tumor effects of $\mathrm{CD} 4^{+} \mathrm{T}$ cells. In our study, $\mathrm{CD}^{+} \mathrm{T}$ cells were not as essential as $\mathrm{CD} 8^{+} \mathrm{T}$ cells for the therapeutic effect of RT and $1400 \mathrm{~W}$ combination treatment. The depletion of $\mathrm{CD}^{+} \mathrm{T}$ cells completely abrogated the suppression of the irradiated tumor. However, $\mathrm{CD}^{+} \mathrm{T}$ cell depletion had minimal effect, which demonstrated the indispensable role of $\mathrm{CD}^{+} \mathrm{T}$ cells.

Tumor-infiltrating myeloid-derived cells are mainly composed of dendritic cells, MDSCs, polymorphonuclear neutrophils, and TAMs. In our co-culture experiments in vitro, we selected THP-1 cells, which could differentiate into immunosuppressive macrophages. We verified the interaction between these macrophages and T cells. Interestingly, flow cytometry showed no effect of iNOS inhibition on the levels of tumor-infiltrating myeloid-derived suppressor cells. The inhibition of iNOS might be more involved in the interaction between myeloidderived cells and $T$ cells, rather than directly acting on the former.

To investigate the mechanism through which local RT influenced the anti-tumor immune response, we examined the serum levels of cytokines relevant to inflammation. Previous studies showed that IFN- $\gamma$ and IL-2 appeared to be immune-promoting. IFN- $\gamma$ had a tumor cell-killing effect [47], while IL-2 was involved in facilitating CD8+ T cell differentiation and activation [48]. IL-4 and IL-5 were known as immunosuppressive cytokines [49]. Our data showed that combined treatment increased the serum levels of IFN- $\gamma$ and IL-2, which indicated a synergistic antitumor effect of RT and 1400W. Interestingly, our data showed no differences among groups of the other three cytokines, IL-4, IL-5 and TNF- $\alpha$, which were pro-inflammatory cytokines.

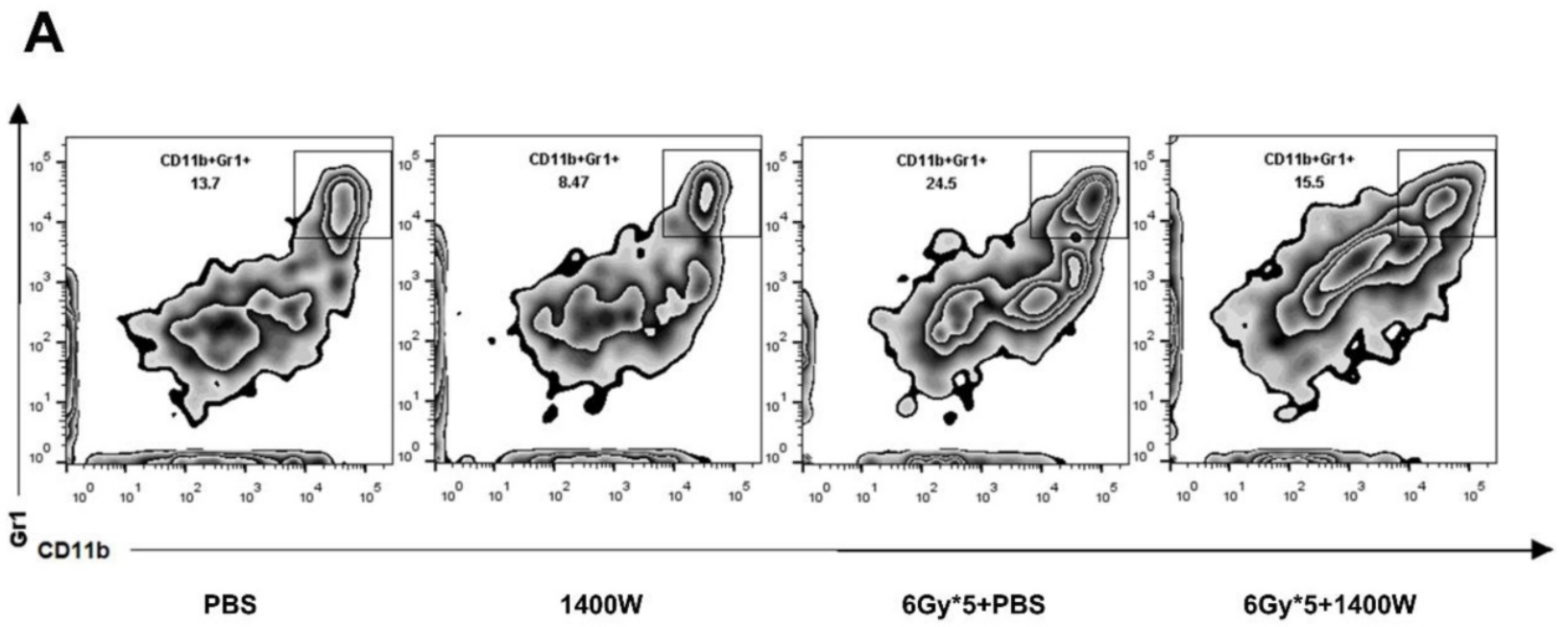

B

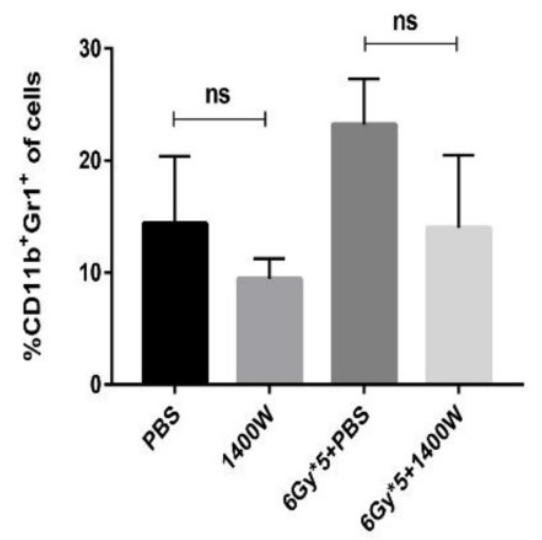

Figure 4. iNOS inhibition had no effect on the levels of tumor-infiltrating myeloid-derived suppressor cells. (A): Representative cytometry of tumor-infiltrating MDSCs in lung cancer tissues. (B): Quantitative analysis of MDSCs in lung cancer tissues. $n \geq 3$; $n$, not significant. 
A

PBS

1400W

$6 G y^{*} 5+P B S$

$6 G y^{\star} 5+1400 W$

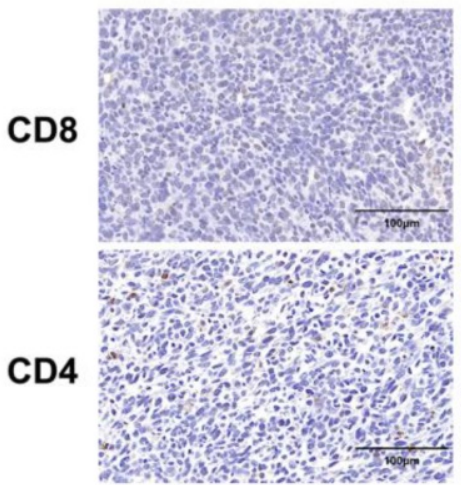

B

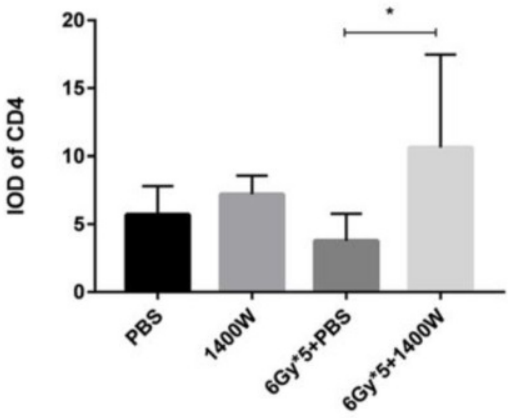

E

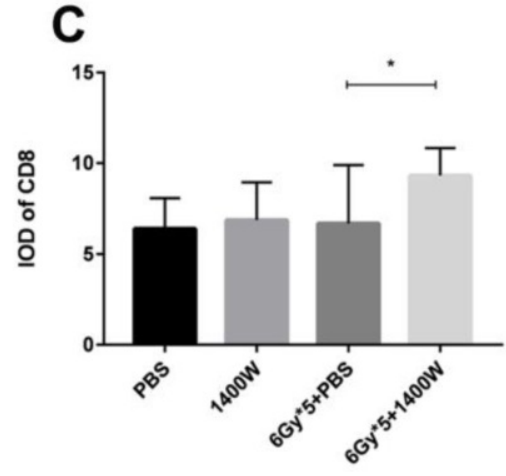

D
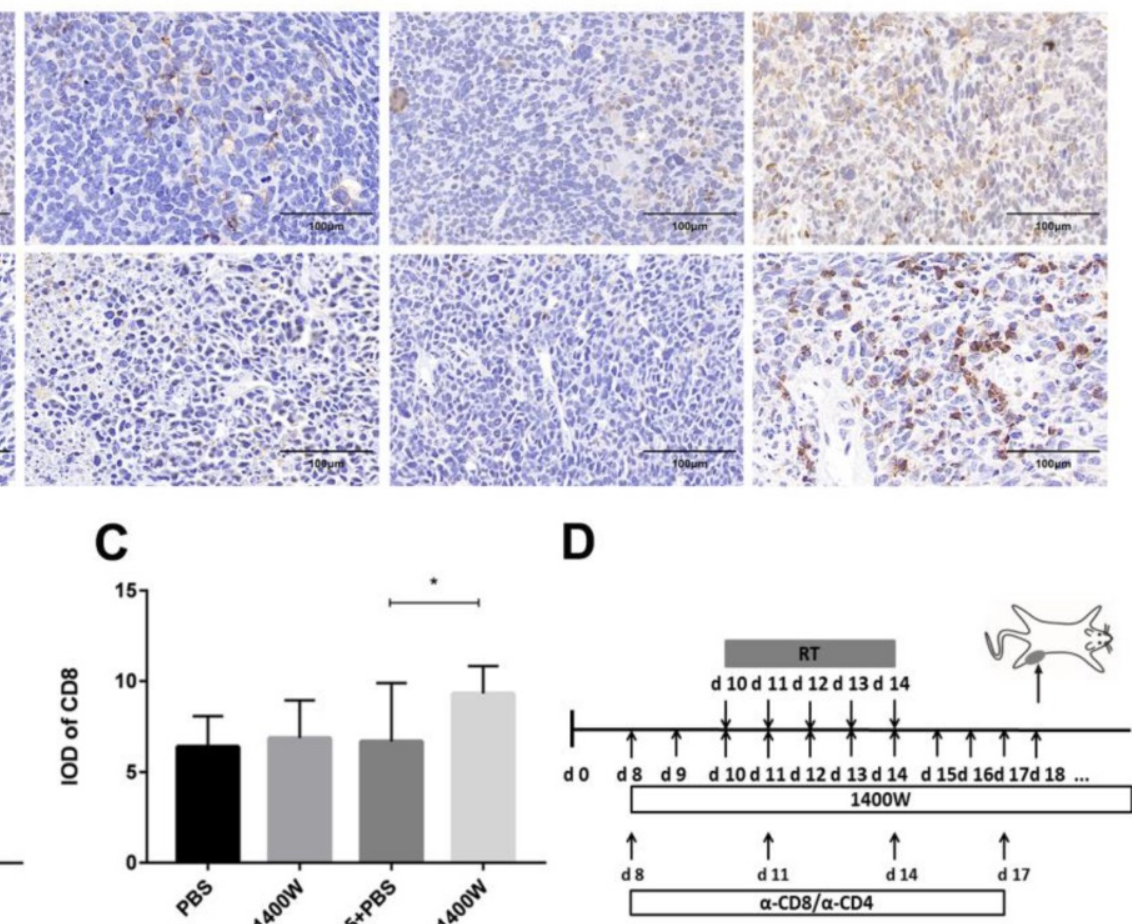

$\mathbf{F}$
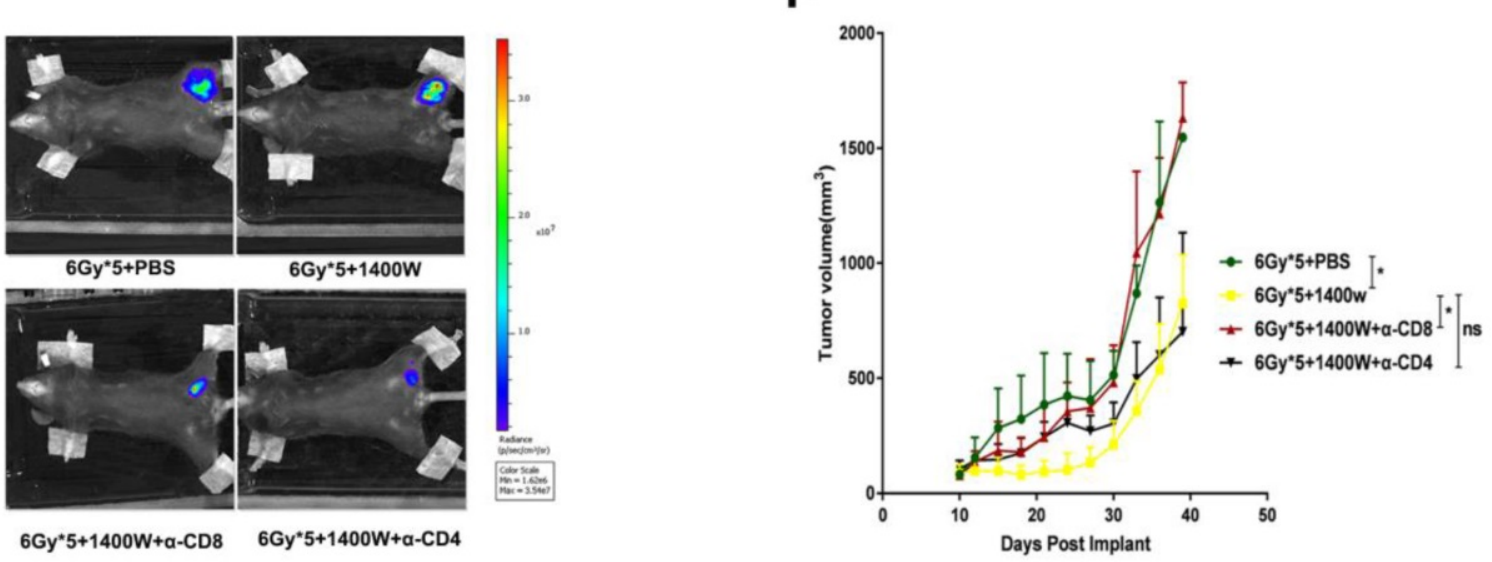

G

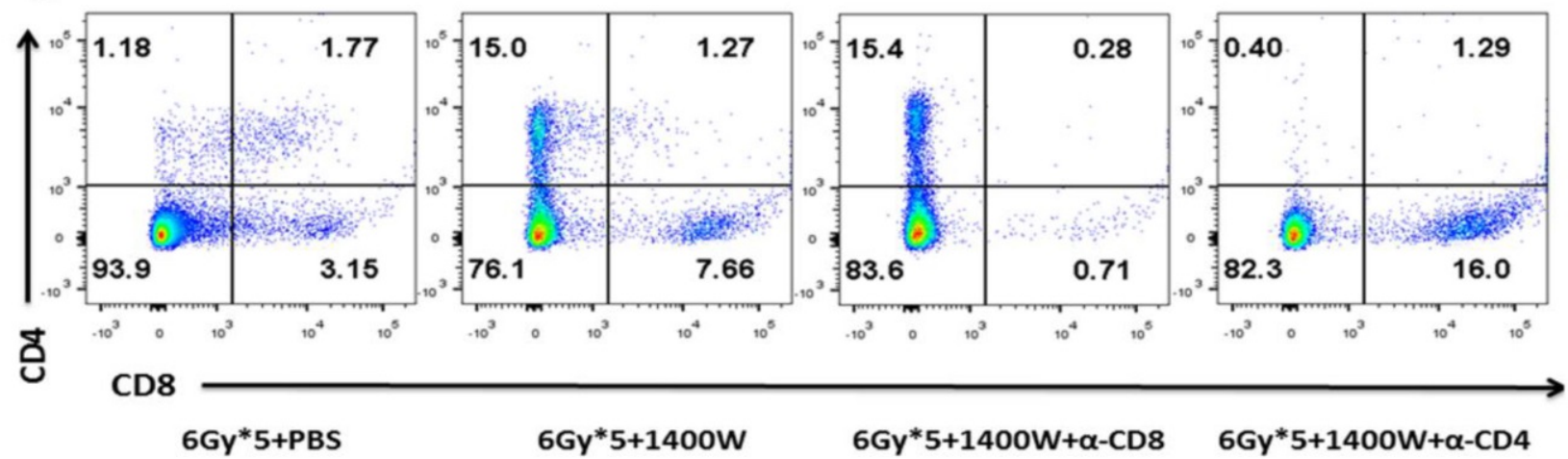

Figure 5. CD8+ T cells mediated the increased efficacy of RT by iNOS inhibition. (A): Representative immunohistochemistry images of CD4+ and CD8+ $T$ cells in lung cancer tissues. (B-C): Quantification of $C D 4^{+}$and $C D 8^{+} T$ cells in lung cancer tissues. *, $P<0.05$. (D): Treatment schema for CD8 $8^{+}$and $C D 4^{+} T$ cell depletion study. (E): Representative in vivo images of mice with $C D 8^{+}$or $C D 4^{+} T$ cell depletion. $(F)$ : Tumor growth curves of mice with $C D 8+$ or $C D 4+T$ cell depletion. *, $P<0.05$. (G): Analysis of peripheral blood lymphocytes to verify the depletion of $\mathrm{CD} 8^{+}$or $\mathrm{CD} 4^{+} \mathrm{T}$ cells. 

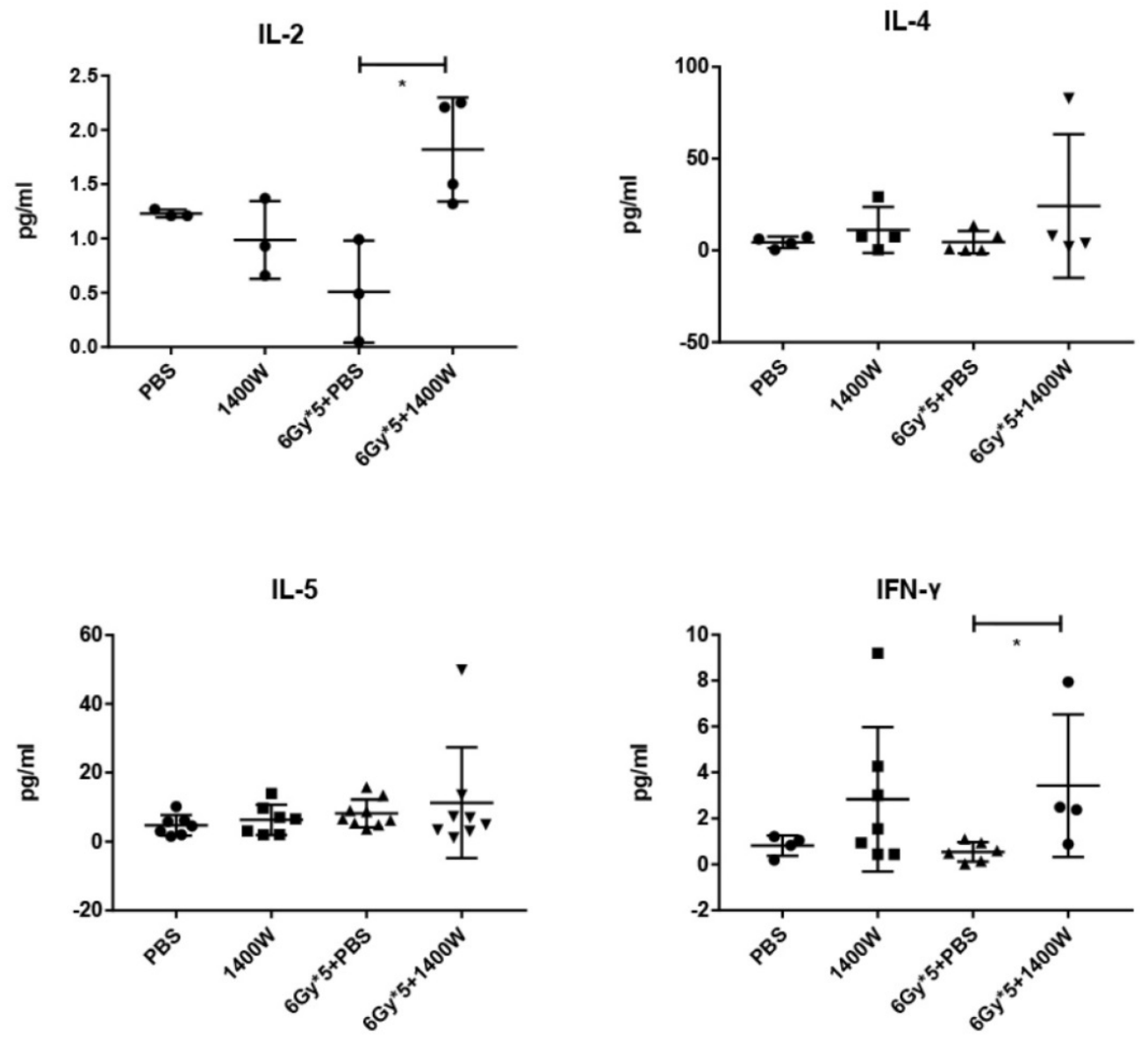

TNF- $\alpha$

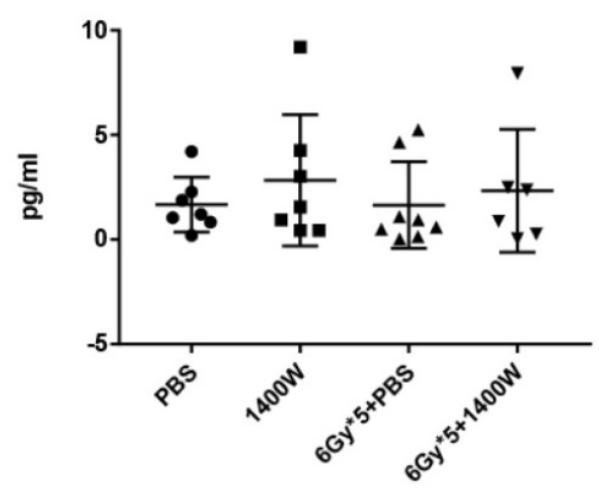

Figure 6. The combination of iNOS inhibition and RT increased IL-2 amd IFN-y levels in the serum. The serum levels of IL-4, IL-5 and TNF- $\alpha$ were comparable between groups. $\mathrm{n} \geq 3$; $*, \mathrm{P}<0.05$.

RT can induce the immunogenic death of tumor cells and the subsequent generation of DAMPs contributes to the efficacy of radiation-induced in situ vaccines [50]. After treatment with a combination of $\mathrm{RT}$ and $1400 \mathrm{~W}$, both the increase in $\mathrm{CD}^{+} \mathrm{T}$ cell infiltration in the spleen and the up-regulation of certain inflammatory cytokines in serum, showed that this treatment was effective at activating systemic immunity. It has been reported that NO is the agent produced by TAMs that can directly interfere with $\mathrm{T}$ cell activation and proliferation [2-4, 31, 32]. Our in vitro data also demonstrated that the addition of an iNOS inhibitor abrogated the suppression of $\mathrm{T}$ cell proliferation by irradiated THP-1-derived macrophages. 
PBS

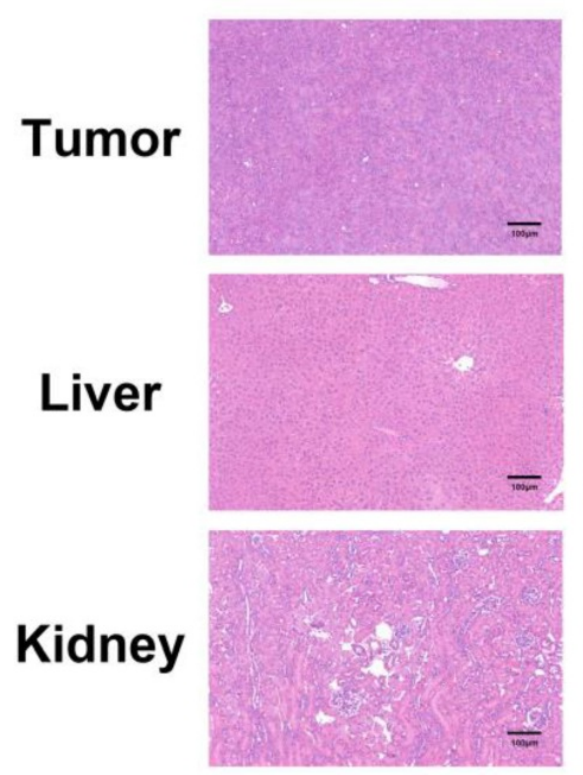

1400W
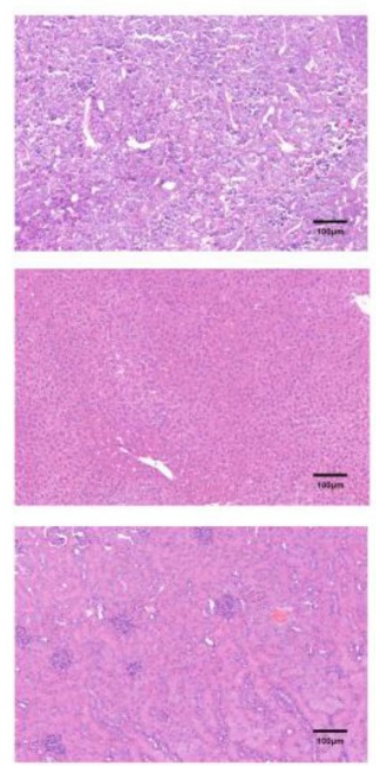

$6 G{ }^{\star} 5+P B S \quad 6 G y * 5+1400 W$
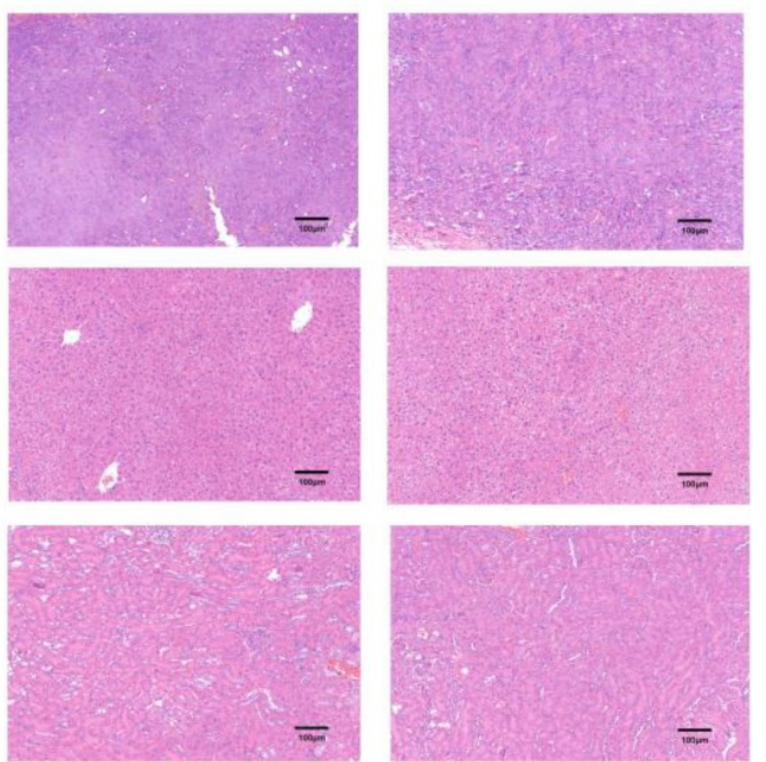

Figure 7. Representative hematoxylin and eosin staining images of lung cancer tissues, liver and kidney. No obvious organ toxicity was induced by the combination of iNOS inhibition and RT.

A

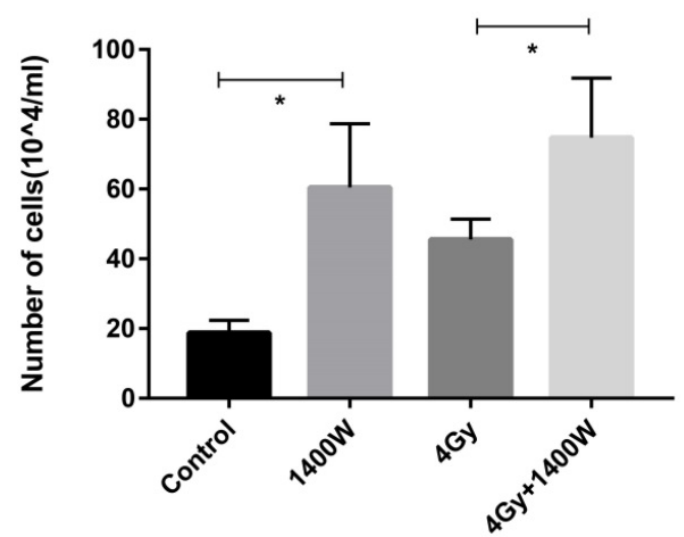

B

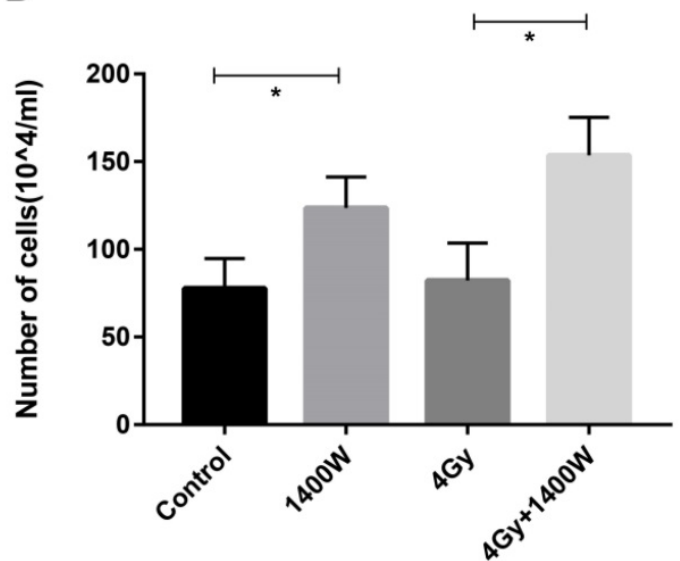

Figure 8. iNOS inhibition neutralized myeloid cell-induced inhibition of $\mathbf{T}$ cell proliferation in vitro. The supernatant was collected in the THP- 1 cell culture $12 \mathrm{~h}$ (A) and $24 \mathrm{~h}$ (B) after irradiation and applied to Jurkat cells. The number of viable Jurkat cells was examined using blood cell counting plate $24 \mathrm{~h}$ later. $\mathrm{n} \geq 3$; *, $\mathrm{P}<0.05$.

\section{Conclusions}

In this study, our in vivo assays demonstrated that iNOS inhibition combined with RT led to an apparent increase in tumor- and spleen-infiltrating $\mathrm{CD}^{+} \mathrm{T}$ cells and upregulated serum inflammatory cytokine levels. Moreover, our in vitro experiments indicated that iNOS blockade neutralized the inhibitory effects of myeloid cells on $\mathrm{T}$ cell proliferation. The mechanism whereby iNOS inhibition sensitizes RT was thus revealed. Our findings supported the potential of $1400 \mathrm{~W}$ as a radiation sensitizer for application in combined therapies to treat various solid tumors.

\section{Abbreviations}

NO: nitric oxide; iNOS: inducible NO synthase; RT: radiotherapy; MDSCs: myeloid-derived suppressor cells; TAM: tumor-associated macrophage; LLC: Lewis lung carcinoma; PBS: phosphate-buffered saline; IL: interleukin; IFN: interferon; CBA: Cytometric Bead Array.

\section{Acknowledgements}

The excellent technical assistance of Mr. Dajiang Wang is gratefully acknowledged.

\section{Grant support}

This study was supported by National Natural Science Foundation of China (81572967, 81773236, 
81800429 and 81972852), Health Commission of Hubei Province Medical Leading Talent Project and Scientific Research Project (WJ2019H002 and WJ2019Q047), the Fundamental Research Funds for the Central Universities (2042018kf0065, 2042018kf1037 and 20420 19kf0329), Medical Science Advancement Program (Basic Medical Sciences) of Wuhan University (TFJC20 18005), and Zhongnan Hospital of Wuhan University Science, Technology and Innovation Seed Fund (znpy 2016050, znpy2017001, znpy2017049 and znpy2018028 and znpy2018070).

\section{Author Contributions}

Conceived and designed the study: J.X., Y.G. and C.X. Performed the study: J.X., Y.L. Analyzed the results: J.X., Y.L., C.Y., L.H., Y.G., and C.X. Contributed reagents/ materials/ analysis tools: Q.W., L.X., Y.G., Y.S., S.M., G.T., S.L. and W.S. Wrote the manuscript: J.X., Y.G. and C.X. All authors reviewed and agreed to the publication of the manuscript.

\section{Competing Interests}

The authors have declared that no competing interest exists.

\section{References}

1. Gough MJ, Young K, Crittenden MJC, Immunology D. The impact of the myeloid response to radiation therapy. 2013; 2013: 975-84

2. Mantovani A, Sica A. Macrophages, innate immunity and cancer: balance, tolerance, and diversity. Current opinion in immunology. 2010; 22: 231-7.

3. Qian BZ, Pollard JW. Macrophage diversity enhances tumor progression and metastasis. Cell. 2010; 141: 39-51.

4. Bingisser RM, Tilbrook PA, Holt PG, Kees UR. Macrophage-derived nitric oxide regulates $\mathrm{T}$ cell activation via reversible disruption of the Jak3/STAT5 signaling pathway. Journal of immunology (Baltimore, Md : 1950). 1998; 160: 5729-34

5. Gallina G, Dolcetti L, Serafini P, De Santo C, Marigo I, Colombo MP, et al. Tumors induce a subset of inflammatory monocytes with immunosuppressive activity on CD8+ T cells. The Journal of clinical investigation. 2006; 116: 2777-90.

6. Gajewski TF, Schreiber H, Fu YX. Innate and adaptive immune cells in the tumor microenvironment. Nature immunology. 2013; 14: 1014-22.

7. Parker KH, Beury DW, Ostrand-Rosenberg S. Myeloid-Derived Suppressor Cells: Critical Cells Driving Immune Suppression in the Tumor Microenvironment. Advances in cancer research. 2015; 128: 95-139.

8. Geissmann F, Gordon S, Hume DA, Mowat AM, Randolph GJ. Unravelling mononuclear phagocyte heterogeneity. Nature reviews Immunology. 2010; 10: 453-60

9. Rodriguez PC, Ochoa AC. Arginine regulation by myeloid derived suppressor cells and tolerance in cancer: mechanisms and therapeutic perspectives. Immunological reviews. 2008; 222: 180-91.

10. Schmielau J, Finn OJ. Activated granulocytes and granulocyte-derived hydrogen peroxide are the underlying mechanism of suppression of $\mathrm{t}$-cell function in advanced cancer patients. Cancer research. 2001; 61: 4756-60.

11. Bronte V, Serafini P, De Santo C, Marigo I, Tosello V, Mazzoni A, et al. IL-4-induced arginase 1 suppresses alloreactive T cells in tumor-bearing mice. Journal of immunology (Baltimore, Md : 1950). 2003; 170: 270-8.

12. Knowles RG, Moncada S. Nitric oxide synthases in mammals. The Biochemical journal. 1994; 298 ( Pt 2): 249-58

13. Ridnour LA, Thomas DD, Donzelli S, Espey MG, Roberts DD, Wink DA, et al. The biphasic nature of nitric oxide responses in tumor biology. Antioxidants \& redox signaling. 2006; 8: 1329-37.

14. Michel T, Feron O. Nitric oxide synthases: which, where, how, and why? The Journal of clinical investigation. 1997; 100: 2146-52.

15. Singh S, Gupta AK. Nitric oxide: role in tumour biology and iNOS/NO-based anticancer therapies. Cancer chemotherapy and pharmacology. 2011; 67: 1211-24.
16. Rodriguez PC, Zea AH, Culotta KS, Zabaleta J, Ochoa JB, Ochoa AC. Regulation of $\mathrm{T}$ cell receptor CD3zeta chain expression by L-arginine. The Journal of biological chemistry. 2002; 277: 21123-9.

17. Rodriguez PC, Quiceno DG, Ochoa AC. L-arginine availability regulates T-lymphocyte cell-cycle progression. Blood. 2007; 109: 1568-73.

18. Rodriguez PC, Quiceno DG, Zabaleta J, Ortiz B, Zea AH, Piazuelo MB, et al. Arginase I production in the tumor microenvironment by mature myeloid cells inhibits T-cell receptor expression and antigen-specific T-cell responses. Cancer research. 2004; 64: 5839-49.

19. Newton JM, Hanoteau A, Liu HC, Gaspero A, Parikh F, Gartrell-Corrado RD, et al. Immune microenvironment modulation unmasks therapeutic benefit of radiotherapy and checkpoint inhibition. Journal for immunotherapy of cancer. 2019; 7: 216.

20. Hanoteau A, Newton JM, Krupar R, Huang C, Liu HC, Gaspero A, et al. Tumor microenvironment modulation enhances immunologic benefit of chemoradiotherapy. Journal for immunotherapy of cancer. 2019; 7: 10.

21. Saleem W, Suzuki Y, Mobaraki A, Yoshida Y, Noda S, Saitoh JI, et al. Reduction of nitric oxide level enhances the radiosensitivity of hypoxic non-small cell lung cancer. Cancer science. 2011; 102: 2150-6.

22. Deng L, Liang H, Burnette B, Beckett M, Darga T, Weichselbaum RR, et al. Irradiation and anti-PD-L1 treatment synergistically promote antitumor immunity in mice. The Journal of clinical investigation. 2014; 124: 687-95.

23. Rus A, Castro L, Del Moral ML, Peinado A. Inducible NOS inhibitor 1400W reduces hypoxia/re-oxygenation injury in rat lung. Redox report communications in free radical research. 2010; 15: 169-78.

24. Shi Q, Liu X, Wang N, Zheng X, Ran J, Liu Z, et al. 1400W ameliorates acute hypobaric hypoxia/reoxygenation-induced cognitive deficits by suppressing the induction of inducible nitric oxide synthase in rat cerebral cortex microglia. Behavioural brain research. 2017; 319: 188-99.

25. Staunton CA, Barrett-Jolley R, Djouhri L, Thippeswamy T. Inducible nitric oxide synthase inhibition by $1400 \mathrm{~W}$ limits pain hypersensitivity in a neuropathic pain rat model. Experimental physiology. 2018; 103: 535-44.

26. Puttachary S, Sharma S, Verma S, Yang Y, Putra M, Thippeswamy A, et al. 1400W, a highly selective inducible nitric oxide synthase inhibitor is a potential disease modifier in the rat kainate model of temporal lobe epilepsy. Neurobiology of disease. 2016; 93: 184-200.

27. Postow MA, Callahan MK, Wolchok JD. The antitumor immunity of ipilimumab: (T-cell) memories to last a lifetime? Clinical cancer research : an official journal of the American Association for Cancer Research. 2012; 18: 1821-3.

28. Topalian SL, Mario S, Mcdermott DF, Kluger HM, Carvajal RD, Sharfman $\mathrm{WH}$, et al. Survival, durable tumor remission, and long-term safety in patients with advanced melanoma receiving nivolumab. J Clin Oncol. 2014; 32: 1020-30.

29. Lugade AA, Moran JP, Gerber SA, Rose RC, Frelinger JG, Lord EM. Local radiation therapy of $\mathrm{B} 16$ melanoma tumors increases the generation of tumor antigen-specific effector cells that traffic to the tumor. Journal of immunology (Baltimore, Md : 1950). 2005; 174: 7516-23.

30. Lee Y, Auh SL, Wang Y, Burnette B, Wang Y, Meng Y, et al. Therapeutic effects of ablative radiation on local tumor require CD8+ T cells: changing strategies for cancer treatment. Blood. 2009; 114: 589-95.

31. Condeelis J, Pollard JW. Macrophages: obligate partners for tumor cell migration, invasion, and metastasis. Cell. 2006; 124: 263-6.

32. Pollard JW. Tumour-educated macrophages promote tumour progression and metastasis. Nature reviews Cancer. 2004; 4: 71-8.

33. Harari $\mathrm{O}$, Liao JK. Inhibition of MHC II gene transcription by nitric oxide and antioxidants. Current pharmaceutical design. 2004; 10: 893-8.

34. Rivoltini L, Carrabba M, Huber V, Castelli C, Novellino L, Dalerba P, et al. Immunity to cancer: attack and escape in T lymphocyte-tumor cell interaction. Immunological reviews. 2002: 188:97-113.

35. Munder M, Schneider H, Luckner C, Giese T, Langhans CD, Fuentes JM, et al. Suppression of T-cell functions by human granulocyte arginase. Blood. 2006; 108: $1627-34$

36. Rodriguez PC, Zea AH, DeSalvo J, Culotta KS, Zabaleta J, Quiceno DG, et al. L-arginine consumption by macrophages modulates the expression of CD3 zeta chain in T lymphocytes. Journal of immunology (Baltimore, Md : 1950). 2003; 171: 1232-9.

37. Lamas B, Vergnaud-Gauduchon J, Goncalves-Mendes N, Perche O, Rossary A, Vasson MP, et al. Altered functions of natural killer cells in response to L-Arginine availability. Cellular immunology. 2012; 280: 182-90.

38. Oberlies J, Watzl C, Giese T, Luckner C, Kropf P, Muller I, et al. Regulation of NK cell function by human granulocyte arginase. Journal of immunology (Baltimore, Md : 1950). 2009; 182: 5259-67.

39. Li LG, Xu HM. Inducible nitric oxide synthase, nitrotyrosine and apoptosis in gastric adenocarcinomas and their correlation with a poor survival. World journal of gastroenterology. 2005; 11: 2539-44.

40. Vakkala M, Kahlos K, Lakari E, Paakko P, Kinnula V, Soini Y. Inducible nitric oxide synthase expression, apoptosis, and angiogenesis in in situ and invasive breast carcinomas. Clinical cancer research : an official journal of the American Association for Cancer Research. 2000; 6: 2408-16.

41. Cianchi F, Cortesini C, Fantappie O, Messerini L, Schiavone N, Vannacci A, et al. Inducible nitric oxide synthase expression in human colorectal cancer: correlation with tumor angiogenesis. The American journal of pathology. 2003; 162: 793-801.

42. Brennan PA, Dennis S, Poller D, Quintero M, Puxeddu R, Thomas GJ. Inducible nitric oxide synthase: correlation with extracapsular spread and 
enhancement of tumor cell invasion in head and neck squamous cell carcinoma. Head \& neck. 2008; 30: 208-14.

43. Pukkila MJ, Kellokoski JK, Virtaniemi JA, Kumpulainen EJ, Johansson RT, Halonen PM, et al. Inducible nitric oxide synthase expression in pharyngeal squamous cell carcinoma: relation to $\mathrm{p} 53$ expression, clinicopathological data, and survival. The Laryngoscope. 2002; 112: 1084-8.

44. Glynn SA, Boersma BJ, Dorsey TH, Yi M, Yfantis HG, Ridnour LA, et al. Increased NOS2 predicts poor survival in estrogen receptor-negative breast cancer patients. The Journal of clinical investigation. 2010; 120: 3843-54.

45. Rodriguez-Ruiz ME, Rodriguez I, Garasa S, Barbes B, Solorzano JL, Perez-Gracia JL, et al. Abscopal Effects of Radiotherapy Are Enhanced by Combined Immunostimulatory mAbs and Are Dependent on CD8 T Cells and Crosspriming. Cancer research. 2016; 76: 5994-6005.

46. Yu H, Ou Y, Shang $\mathrm{Q}$, Yan $\mathrm{C}$, Peng J, Wang $\mathrm{X}$, et al. The clinical effects of low-dose splenic irradiation combined with chest three-dimensional conformal radiotherapy on patients with locally advanced non-small-cell lung cancer: a randomized clinical trial. Onco Targets Ther. 2016; 9: 5545-52

47. Burnette BC, Liang H, Lee Y, Chlewicki L, Khodarev NN, Weichselbaum RR, et al. The efficacy of radiotherapy relies upon induction of type i interferon-dependent innate and adaptive immunity. Cancer research. 2011; 71: 2488-96.

48. Liao W, Lin JX, Leonard WJ. Interleukin-2 at the crossroads of effector responses, tolerance, and immunotherapy. Immunity. 2013; 38: 13-25.

49. Stout RD, Watkins SK, Suttles J. Functional plasticity of macrophages: in situ reprogramming of tumor-associated macrophages. Journal of leukocyte biology. 2009; 86: 1105-9.

50. Formenti SC, Demaria S. Local control by radiotherapy: is that all there is? Breast cancer research : BCR. 2008; 10: 215. 